\title{
THE DEPENDENCE OF TRIBAL LIVELIHOODS ON FOREST FRUITS IN RURAL JHARKHAND, INDIA
}

\author{
M.A. Islam ${ }^{*}$, Angrej Ali², A.M. Ansari ${ }^{3}$ \\ ${ }^{1}$ Division of Natural Resource Management, Faculty of Forestry, SKUAST-K, Benhama, Ganderbal-191201 (J\&K), India \\ ${ }^{2}$ Department of Horticulture, Faculty of Agriculture, SKUAST-K, Wadura, Sopore-193201 (J\&K), India \\ ${ }^{3}$ Zonal Research Station, Birsa Agricultural University, Chianki, Palamau-822102 (Jharkhand), India
}

Received - May 04, 2020; Revision - September 06, 2020; Accepted - October 19, 2020

Available Online - October 25, 2020

DOI: http://dx.doi.org/10.18006/2020.8(5).576.585

KEYWORDS
Food security
India
Jharkhand
Livelihoods
Tribes
Forest fruits

\begin{abstract}
This paper explores the diversity, extraction, consumption and livelihood contribution of forest fruits among tribes in Bundu block of Ranchi district, Jharkhand. A multi-stage random sampling technique was employed to draw a sample of 164 households from 9 selected villages for field surveys. Data were collected through a structured interview, non-participant observation, key informant interview, focus group discussion, and market assessment. Simple descriptive statistics viz., frequency (f), percentage (\%), mean $(\mathrm{x})$, and range were applied to analyze the data. Results of the study revealed that 31 forest fruits harvested from 26 trees and 5 shrubs belonging to 28 genera and 21 families and consumed as ripe fruit (24) followed by pickle (9), vegetable (4), oilseed (3), roasted/boiled seed (3), drink (2), dehydrated unripe slices (1), fruit aril (1), fruit leather (1), kernel (1), sauce (1), soar product (1) and vinegar (1). Total extraction of forest fruits was $19312.60 \mathrm{~kg} /$ year, of which $70.37 \%$ was sold for cash income and the rest $29.63 \%$ were consumed for subsistence. Sale of forest fruits accrued an annual income of ₹ 246685.00 which contributed $3.90 \%$ of the total household annual income. Forest fruits constitute a key source of food, nutrition, subsistence, cash income and safety nets. Overharvesting of forest fruits to mitigate livelihood stress is likely to deplete their availability which would greatly affect the tribal welfare and food security. To promote forest fruit's conservation, forest management should be harmonized with tribal development, poverty alleviation, food security, and livelihood sustainability strategies and thus, some additional policies will be required.
\end{abstract}

* Corresponding author

E-mail: ajaztata@gmail.com (M.A. Islam)

Peer review under responsibility of Journal of Experimental Biology and Agricultural Sciences.

Production and Hosting by Horizon Publisher India [HPI] (http://www.horizonpublisherindia.in/).

All rights reserved.
All the articles published by Journal of Experimental Biology and Agricultural Sciences are licensed under a Creative Commons Attribution-NonCommercial 4.0 International License Based on a work at www.jebas.org.

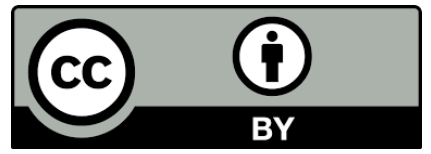




\section{Introduction}

Forest fruits are an indispensable source of diet, food, nutrition, health care, and livelihood for poor people in rural areas throughout the world (Srivastava, 2013; Biswas et al., 2018; Hazarika \& Marak, 2019). These fruits serve as a crucial constituent of the human diet supplying the minerals, vitamins, hormone precursors, protein fibers, polyphenols, antioxidants, and energy (Seal et al., 2014; Shah et al., 2019). Consumption of these forest fruits reduces the risk of several ailments like diabetes, cancer, heart disease, neurodegenerative disorders, etc. (Gireesha \& Raju, 2013; Sarmah et al., 2013; Zhai et al., 2020). Uses of forest fruits as a diet supplement or as a coping mechanism in food shortage times provide an important safety net for the rural people (Mahapatra \& Panda, 2012; Chakraborty \& Chaturvedi, 2014). In developing countries, forest fruits contribute up to $80 \%$ of the population's dietary, health and nutritional needs (Majumdar \& Datta, 2009; Muzaffer et al., 2016). Forest fruits offer diet diversity and have become a valuable livelihood strategy and alternative option for rural poor during food insecurity and nutritional stress (Khatoon et al., 2012; Brahma et al., 2013). Some forest fruits are reported to be more nutritious than conventionally cultivar fruits (Hegazy et al., 2019; Shan et al., 2019). Besides food and nutrition, the utilization of forest fruits also satisfies the socio-economic, cultural, religious, spiritual, and ethnobotanical aspirations of the forest dwellers and primitive communities (Neudeck et al., 2012; Lyngdoh et al., 2016). The forest fruits have gained global attention due to a significant role in ensuring food and livelihood security in underdeveloped and developing countries of the world (Seyoum et al., 2015; Abdullah et al., 2020).

The forests of Bundu block of Ranchi district in Jharkhand, India is bestowed with a considerable diversity of forest fruits constituting an important source of food, nutrition, and livelihoods of tribal communities (Islam \& Quli, 2016). These communities have distinct food habits and dietary traditions and hence, they extract the forest fruits in sizeable quantities since the cultivar fruits are less familiar and not accessible to them. Further, acute poverty and low socio-economic condition also escalate their dependency substantially on forest fruits for household subsistence consumption and cash income. The custom, tradition, spirit, values, taboos, rituals, social and ethical norms possessed by local tribal people have a deep-rooted influence on the cultural inheritance and sustainable use and conservation of forest fruits (Slathia et al., 2017). Traditional knowledge is an indispensable part of the tribal culture and the essence of their social capital coevolved over the ages to adjust with the needs and interests of the surrounding environments and transmitted from generations (Sinha \& Lakra 2005; Mairh et al., 2010). The traditional practices prevalent and practiced by the tribes need to be preserved and practiced to ensure the judicious use and management of precious diminishing natural resources (Singh et al., 2012). The exploration, documentation, preservation, and popularization of forest fruits are very important as cheap sources of food for human consumption and livelihood sustenance (Biswas et al., 2018; Hazarika \& Marak, 2019). The values of these forest fruits persuade to employ a judicious management plan to conserve these resources for sustainable and continued supply for the future generation (Deb et al., 2013). Unfortunately, the traditional wisdom of tribal communities about the local forest fruits is diminishing because the primitive cultures are getting eroded (Mahapatra \& Panda, 2012). Information on forest fruits has the potential to address the food insecurity and can act as a low cost option in development strategies for food security of the rural poor (Dangwal et al., 2014). Over the past few years, the widespread reliance of tribal people on forest fruits has spawned a growing scientific interest among researchers, policymakers, and development practitioners in developing countries (Shivprasad et al., 2016). Further, such scientific studies on forests-people interactions are essential tools in devising alternative strategies for food and livelihood security, poverty reduction and forest conservation (Gangte et al., 2013). Notwithstanding, with a few noteworthy exceptions, there is little empirical research on the traditional wisdom and people's dependence on forest fruits for food and livelihood security. Considering these facts, this study was undertaken to document essential information on forest fruits, their diversity, seasonality, distribution, mode of use, quantity extracted, subsistence consumption, cash income, and employment.

\section{Materials and Methods}

\subsection{Study area, population statistics and climate}

The study was conducted in Bundu block of Ranchi district in Jharkhand, India lying between $23^{0} 11^{\prime}-23^{0} 18^{\prime}$ North latitude and $85^{0} 35^{\prime}-85^{0} 58^{\prime}$ East longitude at an altitude of $337 \mathrm{~m}$ above MSL. It extends over a geographical area of 25097 ha and the major land covers are un-irrigated cultivable land $(69.25 \%)$, forest $(17.44 \%)$, irrigated cultivable land $(8.41 \%)$, culturable wasteland $(3.59 \%)$, unculturable wasteland $(1.29 \%)$ and non-agricultural use $(0.02 \%)$. The major forest type in the block is northern tropical dry deciduous forests $(5 B / C 2)$ (Champion \& Seth, 1968) which falls under Bundu Range of Khunti Forest Division. Total population is 62509 people (31624 males and 30885 females) inhabiting 11495 households of 88 villages (Anonymous, 2009). The block has 23572 literate people (16084 males and 7488 females) which accounts for $44.02 \%$ of the total population. The major livelihood activities include agriculture, NTFPs collection, and livestock production. The climate is dominantly tropical having three distinct seasons, summer, monsoon and winter. The block has an erratic rainfall of $1413.60 \mathrm{~mm}$; the mean minimum temperature of $24^{\circ} \mathrm{C}$ and a mean maximum temperature of $37.2^{\circ} \mathrm{C}$ (Sahu, 2008). 


\subsection{Sampling, data collection and analysis}

Before the survey, all the secondary data relevant to the study were gathered from all possible sources. Based on the baseline information multi-stage random sampling technique (Ray \& Mondol, 2004) was adopted to select a representative sample of 164 households from the 9 selected villages in the block for field survey. Field data collection in the sample households was carried out using personal interviews, non-participant observations, semistructure interviews, focus group discussion and periodical market assessments (Mukherjee, 1993). The survey was carried out using a structured interview schedule aimed at capturing both qualitative and quantitative information. Non-participant observations were structured to interact and record the respondent's behaviors for empirical aims in the natural situation. Using the checklist questions, the valuable key informants were interviewed for information collection on various relevant issues. The focus group discussions were undertaken involving eight to twelve members where the lead author served as a facilitator while the insiders fully participated in the dialogue. Several major relevant issues were raised for discussion which helped to cross-check and validate the data generated. Periodical market inventories were conducted in nearby local markets to record the market prices of different forest fruits. The information documented were common/vernacular names of forest fruits, seasonality, mode of consumption, quantity collected, subsistence consumption, quantity marketed, sale rate, subsistence income, cash income, total income, employment generation and gross annual income consisted of various livelihood sources. The data were analyzed by simple descriptive statistics viz., frequency (f), percentage (\%), mean (x) and range (Snedecor $\&$ Cochran, 1967), and the results were displayed trough charts and tables.

\section{Results and Discussion}

\subsection{Diversity and consumption mode of forest fruits}

The study documented 31 forest fruits belonging to 28 genera and 21 families which were commonly collected and consumed by the tribal communities to meet their daily food and nutritional needs (Table 1). The family Moraceae had the highest representation with five forest fruits followed by Anacardiaceae (4), Rubiaceae (2), Rutaceae (2), Sapindaceae (2), Alangiaceae (1), Anacardiaceae (1), Anonaceae (1), Apocynaceae (1), Arecaceae (1), Caesalpiniaceae (1), Dilleniaceae (1), Dipterocarpaceae (1), Ebenaceae (1), Euphorbiaceae (1), Lecythidaceae (1), Meliaceae (1), Mimosaceae (1), Myrtaceae (1), Rhamnaceae (1) and Rosaceae (1) (Figure 1). Fruits were mainly consumed as ripe fruit (24) with few as a pickle (9), vegetable (4), oilseed (3), roasted/boiled seed (3), drink (2), dehydrated unripe slices (1), fruit aril (1), fruit leather (1), kernel (1), sauce (1), soar product (1) and vinegar (1) by the tribal people (Figure 2). The fruits were mostly (26) collected from trees while the rest (5) were produced by shrubs (Figure 3). Although, the forest fruits were harvested around the year but more than half the fruits (61.29\%) are available during the monsoon season only, i.e. between June and October (Table 1).

The diversity of forest fruits consumed reflected that the forest of the local landscape is enshrined with rich biological diversity. Forest

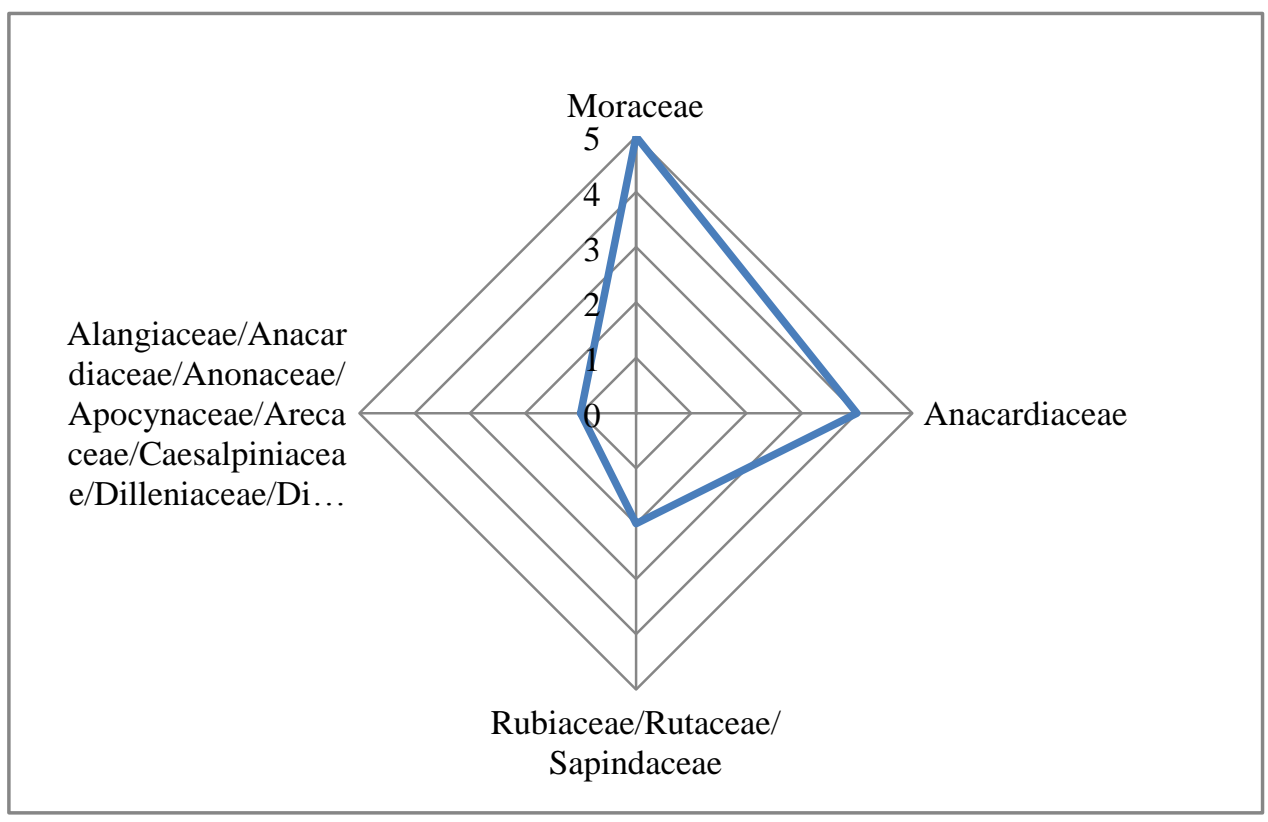

Figure 1 Proportion of forest fruit species by family $(\mathrm{N}=164)$ 
Table 1: Diversity of forest fruits extracted by the tribal people ( $\mathrm{N}=164)$

\begin{tabular}{|c|c|c|c|c|c|}
\hline Species & Family & Local name & $\begin{array}{c}\text { English/ Common } \\
\text { name }\end{array}$ & Seasonality & Mode of consumption \\
\hline Aegle marmelos L. & Rutaceae & Loagassi & Wood apple/ Bel & May-June & Ripe fruit- edible, drink \\
\hline Alangium salvifolium Linn. & Alangiaceae & Dhela & Ankol/ Akola & June-July & Ripe pulp- edible \\
\hline Annona squamosa $\mathrm{L}$. & Anonaceae & Madar & Custard apple/ Sharifal & $\begin{array}{l}\text { July- } \\
\text { September }\end{array}$ & Ripe fruit- edible \\
\hline $\begin{array}{l}\text { Artocarpus heterophylus } \\
\text { Lamk. }\end{array}$ & Moraceae & Kathar & Jackfruit/ Kathal & April-July & $\begin{array}{l}\text { Ripe fruit- edible, unripe fruit- pickle, } \\
\text { vegetable, roasted/ boiled seed- } \\
\text { edible }\end{array}$ \\
\hline $\begin{array}{l}\text { Artocarpus lakoocha } \\
\text { Roxb. }\end{array}$ & Moraceae & Dahu & Monkey jack/ Barhar & March-July & $\begin{array}{l}\text { Ripe fruit- edible, unripe fruit- } \\
\text { vegetable }\end{array}$ \\
\hline Azadirachta indica A. Juss. & Meliaceae & Neem & Indian lilac/ Neem & June- July & Ripe fruit pulp- edible \\
\hline $\begin{array}{l}\text { Buchanania angustifolia } \\
\text { Roxb. }\end{array}$ & Anacardiaceae & Pithwar & Piyala/ Char-pithwar & April-May & Ripe fruit pulp- edible \\
\hline $\begin{array}{ll}\text { Buchanania lanzan } \\
\text { Spreng. }\end{array}$ & Anacardiaceae & Tarob & Chironji/ Piar & April-May & $\begin{array}{l}\text { Ripe fruit- pulp edible, kernel- } \\
\text { confectionary }\end{array}$ \\
\hline Careya arborea Roxb. & Lecythidaceae & Kumbhi & $\begin{array}{l}\text { Slow match tree/ } \\
\text { Kumbhi }\end{array}$ & June- July & Ripe fruit- edible \\
\hline Carissa carandus Linn. & Apocynaceae & Kanwar & Karonda & May-July & Ripe fruit- edible, unripe fruit- pickle \\
\hline Citrus limon (L.) Berm. F. & Rutaceae & $\begin{array}{l}\text { Kagzi } \\
\text { nimbu }\end{array}$ & Lemon/ Lemu & April-June & Ripe fruit- pickle, drink \\
\hline Dillenia indica Linn. & Dilleniaceae & Korkot & Elephant apple/ Rai & $\begin{array}{l}\text { December- } \\
\text { February }\end{array}$ & Ripe fruit- edible, unripe fruit- pickle \\
\hline $\begin{array}{l}\text { Diospyros melanoxylon } \\
\text { Roxb. }\end{array}$ & Ebenaceae & Tiril & Tendu/ Kend & April-May & Ripe fruit- edible \\
\hline Emblica officinalis Gaertn. & Euphorbiaceae & Meral & Aonla/ Amla & $\begin{array}{l}\text { October- } \\
\text { April }\end{array}$ & Ripe fruit- edible, unripe fruit- pickle \\
\hline Ficus glomerata Roxb. & Moraceae & Loa & Indian fig tree/ Gular & Feb-April & $\begin{array}{l}\text { Ripe fruit- edible, unripe fruit- } \\
\text { vegetable }\end{array}$ \\
\hline Ficus infectoria Roxb. & Moraceae & Pakar & Pilkhan/ Dumar & May-June & $\begin{array}{l}\text { Ripe fruit- edible, unripe fruit- } \\
\text { vegetable }\end{array}$ \\
\hline Gardenia latifolia Aiton. & Rubiaceae & Papra & $\begin{array}{ll}\text { Indian } & \text { boxwood/ } \\
\text { Paphar } & \\
\end{array}$ & $\begin{array}{l}\text { December- } \\
\text { January }\end{array}$ & Ripe fruit- edible \\
\hline Madhuca latifolia Macb. & Sapindaceae & Madhucam & $\begin{array}{l}\text { Indian butter tree/ } \\
\text { Mahua }\end{array}$ & June-July & Seed- edible oil \\
\hline Mangifera indica Linn. & Anacardiaceae & Uli & Mango/Aam & May-July & $\begin{array}{l}\text { Ripe fruit- edible, unripe fruit- pickle, } \\
\text { dehydrated slices of green fruit } \\
(A m s i) \text { - sour preparation, fruit leather } \\
(A m t h i) \text { - an important trade article }\end{array}$ \\
\hline Morus alba Linn. & Moraceae & Toont & Mulberry/ Siah Tut & May-June & Ripe fruit- edible \\
\hline $\begin{array}{l}\text { Phoenix acaulis Roxb. ex } \\
\text { Buch. }\end{array}$ & Arecaceae & Kita & Date palm/ Khajur & May-June & Ripe fruit- edible \\
\hline $\begin{array}{l}\text { Pithecolobium dulce } \\
\text { Benth. }\end{array}$ & Fabaceae & Singri & Jangal jalebi & April-June & Fruit aril- Edible \\
\hline Prunus persica Batsch. & Rosaceae & Satalu & Peach & May-June & Ripe fruit- edible \\
\hline Randia uliginosa DC. & Rubiaceae & Piurar & Penaura/ Piurar & $\begin{array}{l}\text { December- } \\
\text { February }\end{array}$ & Ripe fruit- edible \\
\hline $\begin{array}{l}\text { Schleichera oleosa (Lour.) } \\
\text { Oken }\end{array}$ & Sapindaceae & Kusum & Ceylon oak/ Kusum & July-August & Ripe fruit- edible, seed- edible oil \\
\hline $\begin{array}{l}\text { Semecarpus anacardium } \\
\text { Linn. }\end{array}$ & Anacardiaceae & Soso & Marking nut/ Bhelwa & $\begin{array}{l}\text { December- } \\
\text { March }\end{array}$ & Seed- edible \\
\hline $\begin{array}{llll}\text { Shorea robusta } & \text { C. } & \text { F. } \\
\text { Gaertn. } & & & \\
\end{array}$ & Dipterocarpaceae & Sarjom & $\mathrm{Sal} /$ Sakhua & June- August & Seed- edible oil \\
\hline Spondias mangifera Willd. & Anacardiaceae & Ambru & Golden apple/ Amra & $\begin{array}{l}\text { January- } \\
\text { February }\end{array}$ & Unripe fruit- pickle \\
\hline $\begin{array}{l}\text { Syzigium cumini (Linn.) } \\
\text { Skeels }\end{array}$ & Myrtaceae & Kund & Blackberry/ Jamun & June-August & $\begin{array}{l}\text { Ripe fruit- edible, ripe fruit pulp- } \\
\text { vinegar }\end{array}$ \\
\hline Tamarindus indica Linn. & Caesalpiniaceae & Jojo & Tamarind/ Imli & $\begin{array}{l}\text { December- } \\
\text { April }\end{array}$ & $\begin{array}{l}\text { Fruit pulp- sauce, fruit pulp- pickle, } \\
\text { soar preparation, roasted seed- edible }\end{array}$ \\
\hline $\begin{array}{l}\text { Zizyphus } \\
\text { Lamk. }\end{array}$ & Rhamnaceae & $\begin{array}{l}\text { Bakral } \\
\text { Koir }\end{array}$ & Indian jujube/ $\mathrm{Ber}$ & $\begin{array}{l}\text { January- } \\
\text { March }\end{array}$ & Ripe fruit- edible, pickle \\
\hline
\end{tabular}

Journal of Experimental Biology and Agricultural Sciences

http://www.jebas.org 


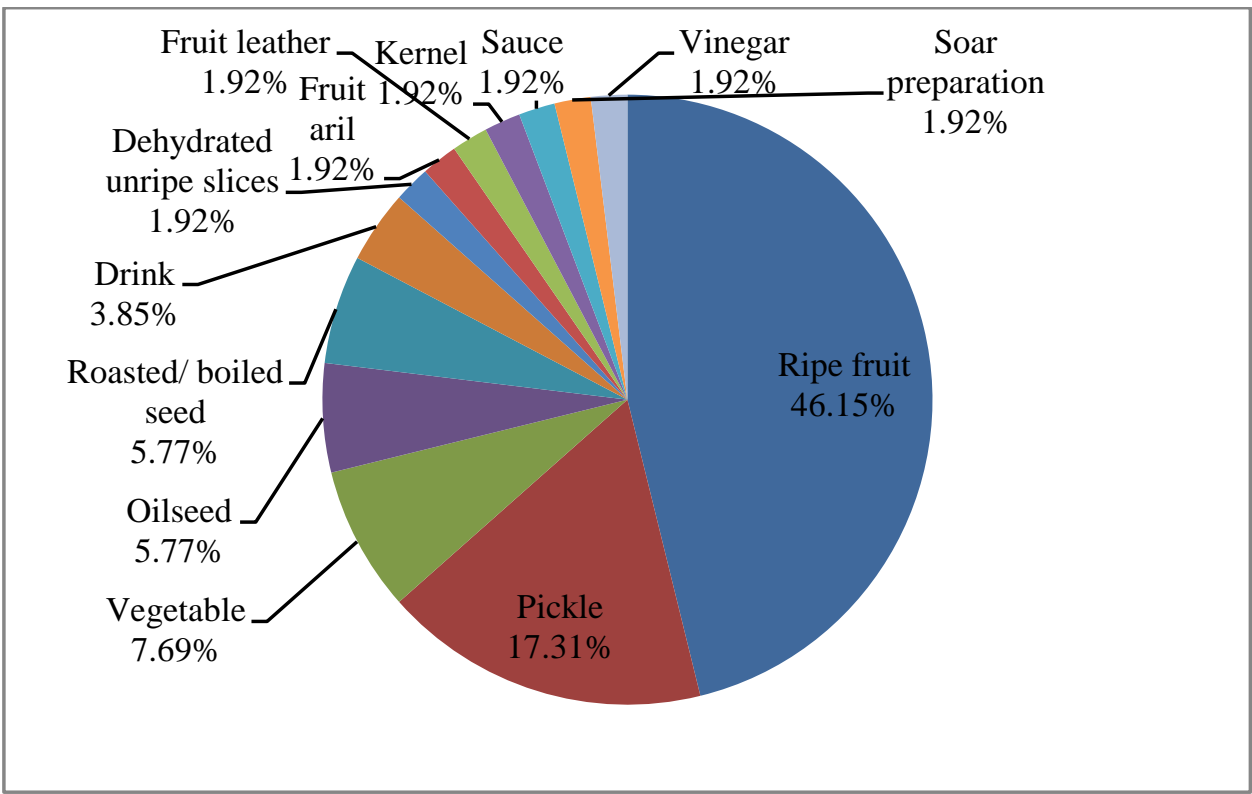

Figure 2 Proportion of forest fruits by consumption mode $(\mathrm{N}=164)$

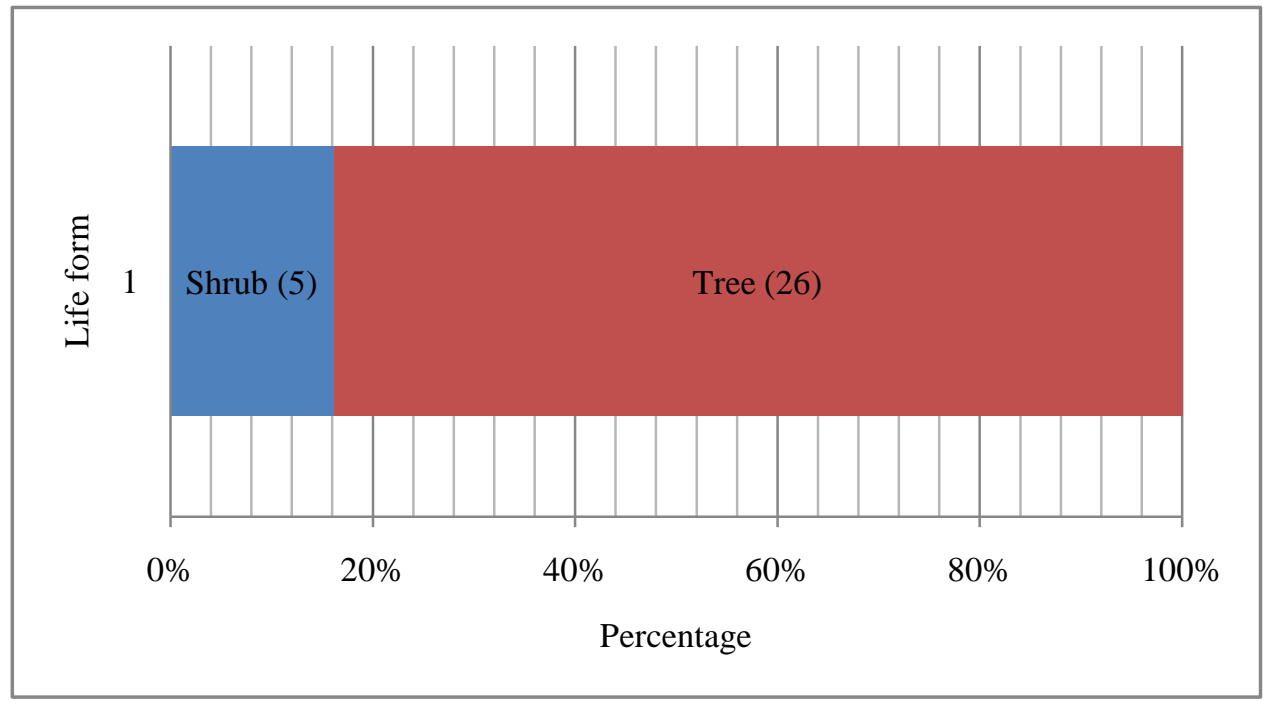

Figure 3 Proportion of forest fruits by life forms $(\mathrm{N}=164)$

fruits constitute the major part of the food basket of the tribal communities. Food and nutritional security is a severe predicament among most of the tribal families (Islam et al., 2015); hence, people harvest and consume a large variety of forest fruits frequently. Forest fruits contribute to food and nutritional security in two ways; first, direct subsistence consumption next to grains and second, sale of fruits to purchase grains in exigency. Due to acute poverty, the poor tribal people are unable to secure a diet rich in carbohydrates, vitamins, protein, sugar, fats, minerals, etc., thus, the forest fruits are the chief sources meeting their daily diet necessities. Marginal returns from crop and livestock products and low employment opportunities have enforced many tribal people to sell the forest fruits in the local weekly markets. As the marketing of edible fruits is unregulated, urban people are unfamiliar to the forest fruits and the middlemen are operational in the trade, the tribal vendors get a very low price which is not remunerative to their labour and time vested. The cash income earned by the sale of the fruits contributes substantially to the household annual income which is primarily used to purchase grains; hence, the fruits are the principal safety net and key coping approach to combat food shortages for the tribal poor. The earlier studies (Seyoum et al., 2015; Islam \& Quli, 2016; Lyngdoh et al., 2016; Muzaffer et al., 2016; Slathia et al., 2017; Biswas et al., 2018; Hazarika \& Marak, 2019; Shah 
et al., 2019; Abdullah et al., 2020) across the world which documented the diversity and food potential of forest fruits confirm that the forest fruits play a significant role in food security, subsistence, cash benefits and safety nets in the tribal communities.

\subsection{Livelihood security through forest fruits}

The total extraction of forest fruits from the forest in the surveyed population was $19312.60 \mathrm{~kg} /$ year @ $4.40 \mathrm{~kg}$ per capita/year. Of the total extraction, $13590.00 \mathrm{~kg}(70.37 \%)$ of the fruits were sold for earnings, and the rest $5722.60 \mathrm{~kg}(29.63 \%)$ fruits were consumed for subsistence by the tribal people (Table 2). The forest fruits fetched a total income of ₹ 246685/year @ ₹1504.18/household/year with an annual employment opportunity of 500.02 man-days @ 3.05 mandays/household/year. The total income included a major share by cash income of ₹178565/year (72.39\%) while the subsistence income contributed a sum of ₹ 68120/year (27.61\%). Mangifera indica L. fetched the maximum cash income of ₹ 31000.00/year while

Table 2 Household income and employment composition by different forest fruits ( $\mathrm{N}=164)$

\begin{tabular}{|c|c|c|c|c|c|c|c|c|}
\hline Forest fruit & $\begin{array}{c}\text { Collection } \\
\text { (kg/year) }\end{array}$ & $\begin{array}{c}\text { Subsistence } \\
\text { consumption } \\
\text { (kg/year) }\end{array}$ & $\begin{array}{c}\text { Sale } \\
\text { (kg/year) }\end{array}$ & $\begin{array}{l}\text { Rate } \\
(₹ / \mathrm{kg})\end{array}$ & $\begin{array}{l}\text { Subsistence } \\
\text { income } \\
\text { (₹/year) }\end{array}$ & $\begin{array}{l}\text { Cash income } \\
\text { (₹/year) }\end{array}$ & $\begin{array}{c}\text { Total } \\
\text { income } \\
\text { (₹/year) }\end{array}$ & $\begin{array}{l}\text { Employment } \\
\text { (man- } \\
\text { days/year) }\end{array}$ \\
\hline Wood apple/ Bel & $1147^{\Delta}$ & $150^{\Delta}$ & $997^{\Delta}$ & $3 / \Delta$ & 450 & 2991 & 3441 & 22.94 \\
\hline Ankol/ Akola & 156 & 156 & 0.00 & 5 & 780 & 0.00 & 780 & 15.60 \\
\hline Custard apple/ Sharifa & 272 & 96 & 176 & 20 & 1920 & 3520 & 5440 & 13.60 \\
\hline Jackfruit/ Kathal & 1065 & 540 & 525 & 5 & 2700 & 2625 & 5325 & 21.30 \\
\hline Monkey jack/ Barhar & 348 & 139 & 209 & 5 & 695 & 1045 & 1740 & 17.40 \\
\hline Indian lilac/ Neem & 41 & 41 & 0.00 & 0.00 & 0.00 & 0.00 & 0.00 & 4.10 \\
\hline Piyala/ Char-pithwar & 73 & 61 & 12 & 5 & 305 & 60.00 & 365 & 7.30 \\
\hline Chironji/ Piar & 168 & 0.00 & 168 & 150 & 0.00 & 25200 & 25200 & 8.40 \\
\hline Slow match tree/ Kumbhi & 7.50 & 7.50 & 0.00 & 0.00 & 0.00 & 0.00 & 0.00 & 1.50 \\
\hline Karonda & 326 & 56 & 270 & 10 & 560 & 2700 & 3260 & 10.52 \\
\hline Lemon/ Lemu & 30 & 10 & 20 & 10 & 100 & 200 & 300 & 4.50 \\
\hline Elephant apple/ Rai & 20 & 20 & 0.00 & 0.00 & 0.00 & 0.00 & 0.00 & 2.0 \\
\hline Tendu/Kend & 420 & 70 & 350 & 10 & 700 & 3500 & 4200 & 8.40 \\
\hline Aonla/ Amla & 250 & 100 & 150 & 10 & 1000 & 1500 & 2500 & 10.00 \\
\hline Indian fig tree/ Gular & 100 & 40 & 60 & 10 & 400 & 600 & 1000 & 10.00 \\
\hline Pilkhan/ Dumar & 80 & 35 & 45 & 10 & 350 & 450 & 800 & 8.0 \\
\hline Indian boxwood/ Paphar & 50 & 20 & 30 & 10 & 200 & 300 & 500 & 5.0 \\
\hline Indian butter tree/ Mahua & 1602 & 150 & 1452 & 12 & 1800 & 17424 & 19224 & 32.04 \\
\hline Mango/ Aam & 2860 & 1310 & 1550 & 20 & 26200 & 31000 & 57200 & 57.20 \\
\hline Mulberry/Siah Tut & 485 & 165 & 320 & 10 & 1650 & 3200 & 4850 & 9.70 \\
\hline Date palm/ Khajur & 550 & 150 & 400 & 10 & 1500 & 4000 & 5500 & 11.00 \\
\hline Jangal jalebi & 20 & 20 & 0.00 & 0.00 & 0.00 & 0.00 & 0.00 & 2.50 \\
\hline Peach & 220 & 40 & 180 & 10 & 400 & 1800 & 2200 & 8.80 \\
\hline Penaura/ Piurar & 50 & 15 & 35 & 10 & 150 & 350 & 500 & 2.50 \\
\hline Ceylon oak/ Kusum & 780 & 195 & 585 & 10 & 1950 & 5850 & 7800 & 15.60 \\
\hline Marking nut/ Bhelwa & 990 & 350 & 640 & 15 & 5250 & 9600 & 14850 & 19.80 \\
\hline Sal/ Sakhua & 450 & 0.00 & 450 & 5 & 0.00 & 2250 & 2250 & 18.00 \\
\hline Golden apple/ Amra & 400 & 150 & 250 & 8 & 1200 & 2000 & 3200 & 10.0 \\
\hline Blackberry/ Jamun & 2016 & 336 & 1680 & 10 & 3360 & 16800 & 20160 & 40.32 \\
\hline Tamarind/ Imli & 1550 & 250 & 1300 & 12 & 3000 & 15600 & 18600 & 31.00 \\
\hline Indian jujube/ Ber & 3550 & 1150 & 2400 & 10 & 11500 & 24000 & 35500 & 71.00 \\
\hline Total & 19312.60 & 5722.60 & 13590 & & 68120 & 178565 & 246685 & 500.02 \\
\hline Average & 117.76 & 34.89 & 82.87 & & 415.37 & 1088.81 & 1504.18 & 3.05 \\
\hline
\end{tabular}

Note: $\Delta=$ pieces; Average weight of wood apple $=0.334 \mathrm{~kg}$

Journal of Experimental Biology and Agricultural Sciences http://www.jebas.org 
Buchanania angustifolia Roxb. accrued lowest income of ₹ 60.00/year in the tribal households.

Forest fruits are boon to the tribal people as it plays a significant role in the traditional food habits, nutrition, and health care and consumed in varied forms as ripe/unripe fruit, pickle, vegetable, oilseed, roasted/boiled seed, drink, dehydrated unripe slices, fruit aril, fruit leather, kernel, sauce, soar product, vinegar, confectionery, and other edible items. Forest fruits are one of the most economically valuable products of northern tropical dry deciduous forests of the block. The most commonly known fruits collected and traded in considerable quantity were Mangifera indica L., Buchanania lanzan Spreng., Zizyphus mauritiana Lamk., Madhuca latifolia Macb., Syzigium cumini (Linn.) Skeels, Tamarindus indica Linn., Semecarpus anacardium Linn., Schleichera oleosa (Lour.) Oken, Phoenix acaulis Roxb. ex Buch., Annona squamosa L., Diospyros melanoxylon Roxb. and Morus alba Linn. Next profitable forest fruits to tribal people include Aegle marmelos L., Carissa carandus Linn., Artocarpus heterophylus Lamk., Shorea robusta C. F. Gaertn., Spondias mangifera Willd., Prunus persica Batsch., Emblica officinalis Gaertn., Artocarpus lakoocha Roxb., Ficus glomerata Roxb., Ficus infectoria Roxb., Randia uliginosa DC., Gardenia latifolia Aiton., Citrus limon (L.) Berm. F., Buchanania angustifolia Roxb., Alangium salvifolium Linn., Azadirachta indica A. Juss., Careya arborea Roxb., Dillenia indica Linn. and Pithecolobium dulce Benth. which were collected and traded comparatively in low quantity. The forest fruits are mainly collected for livelihood earning and only a little fraction is retained for self-consumption. The forest fruits were sold by the primary collectors to the consumers or middlemen at the village level or the local weekly market (Figure 5). The fruits provide different products that, through their subsistence and cash income, are of importance for household livelihoods. The household involvement in collection and marketing differ with the types of fruits, availability, household consumption, market price, and socioeconomic conditions of the tribal people.

The average total annual income of the sample households was ₹ 27894.20 which was mostly constituted by crop (36.24\%), nonfarm (29.88\%), forest $(21.11 \%)$, livestock $(8.86 \%)$, and forest fruits $(3.90 \%)$ (Figure 4). Crop cultivation is the main livelihood source and rain-fed agriculture using dryland varieties of paddy form mainland use. Wage labour, business, shopkeeping, service, remittances, etc. are the major nonfarm sources of income. The tribal households rely on a wide range of economic activities mainly related to forest resource extraction. Forest income contributes substantially to the total income, which was second to crop production, even without the inclusion of income from forest fruits. Sale and consumption of livestock and livestock products are also an important source of income. Concerning income from forest fruits, with an average share of $3.90 \%$ income, it was the fifth contributor to the total income streams in the tribal households. The forest fruits serve as a viable source for both subsistence and cash income because the substitute options are limited or even absent, land for agriculture is very low and the profits to crop or livestock are marginal. Nonetheless, the cash income earned from forest fruits is a bit small; involvement in the trade is an indispensable source of self-esteem, pride, and independence among the tribal people. The studies (Khatoon et al., 2012; Mahapatra \& Panda, 2012; Brahma et al., 2013; Srivastava, 2013; Chakraborty \& Chaturvedi, 2014; Seal et al., 2014; Seyoum et al., 2015; Lyngdoh et al., 2016; Shivprasad et al., 2016; Biswas et al., 2018; Hazarika \& Marak, 2019; Hegazy et al., 2019; Shah et al., 2019) on forest fruits advocate that these forest resources have a significant contribution to the household livelihood security in tribal people.

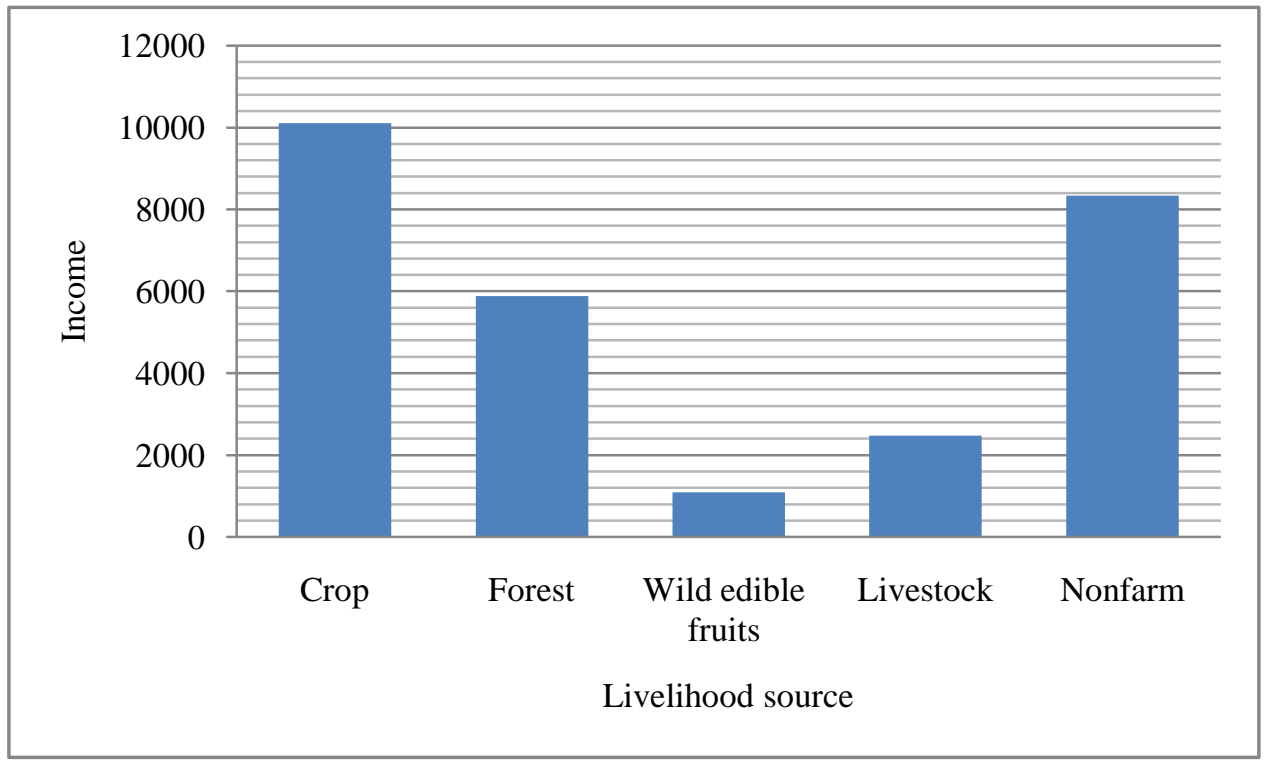

Figure 4 Annual household income by livelihood sources $(\mathrm{N}=164)$

Journal of Experimental Biology and Agricultural Sciences http://www.jebas.org 


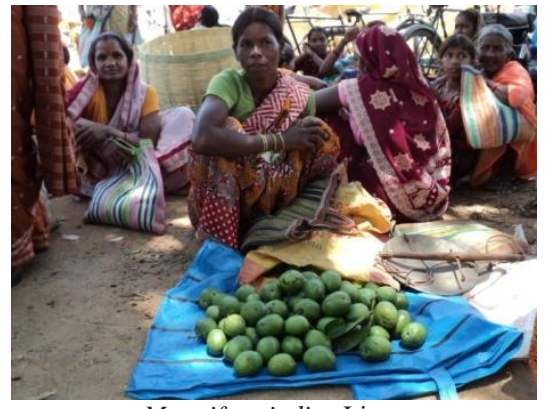

Mangifera indica Linn.

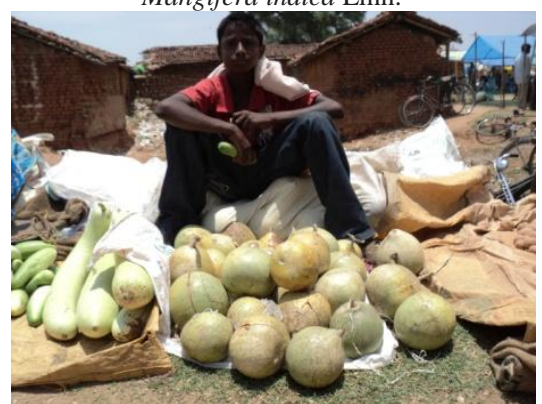

Aegle marmelos L.

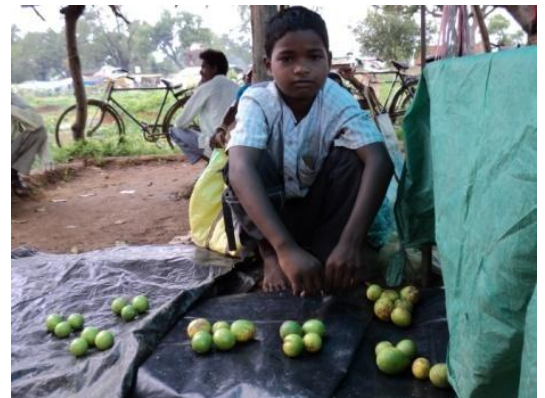

Citrus limon (L.) Berm. F.

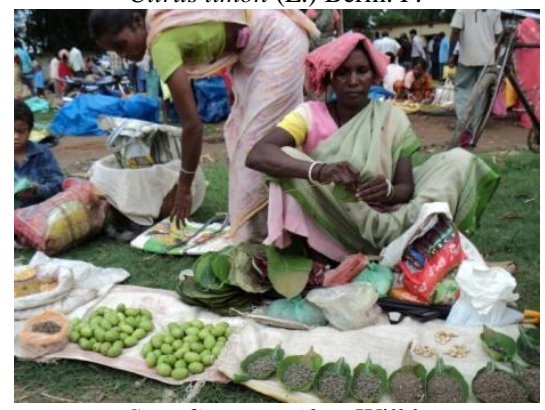

Spondias mangifera Willd.

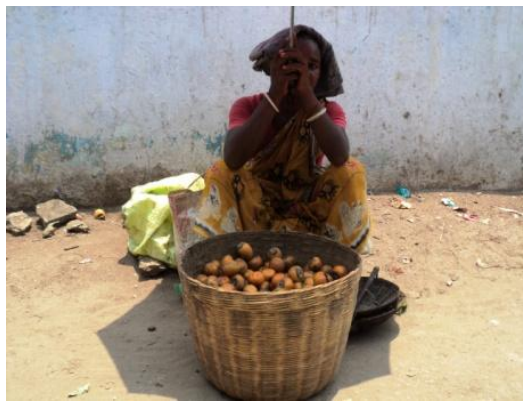

Diospyros melanoxylon Roxb.

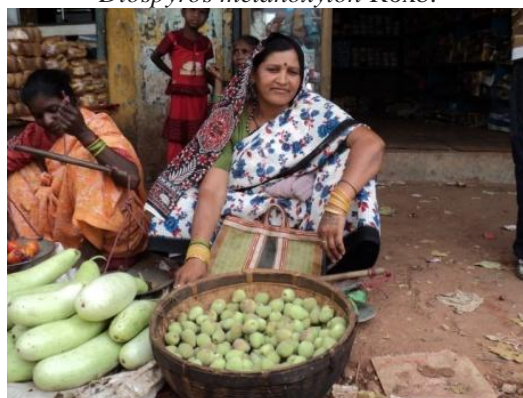

Prunus persica Batsch.

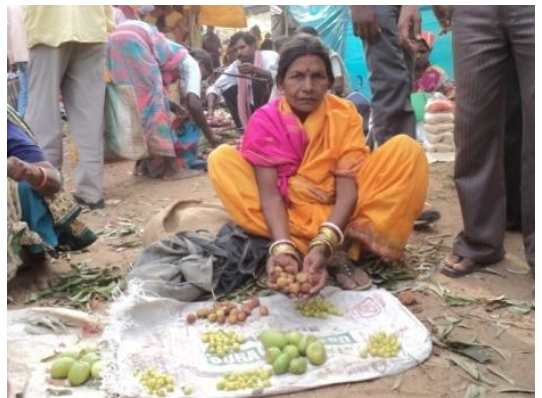

Emblica officinalis Gaertn.

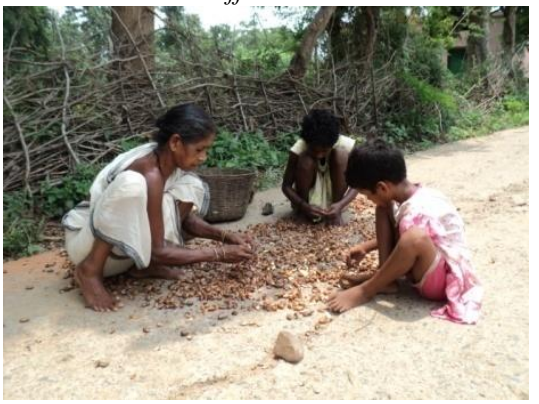

Shorea robusta C. F. Gaertn.

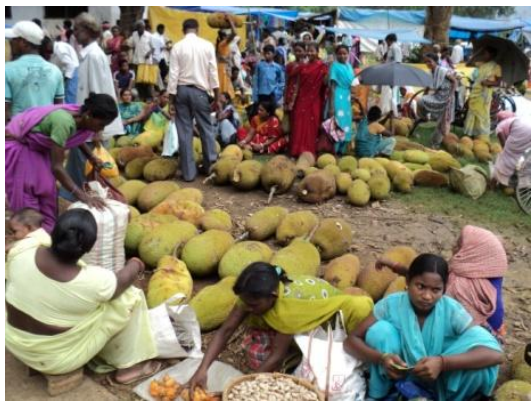

Artocarpus heterophylus Lamk.

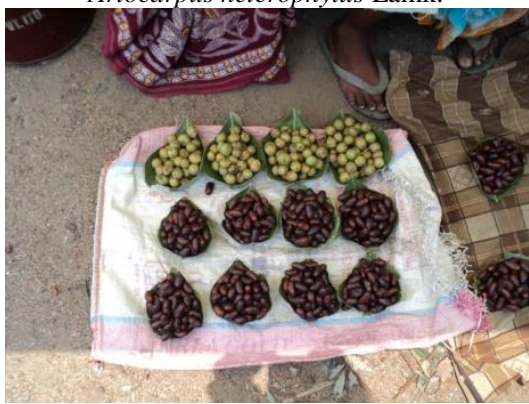

Phoenix acaulis Roxb. ex Buch / Schleichera oleosa (Lour.) Oken.

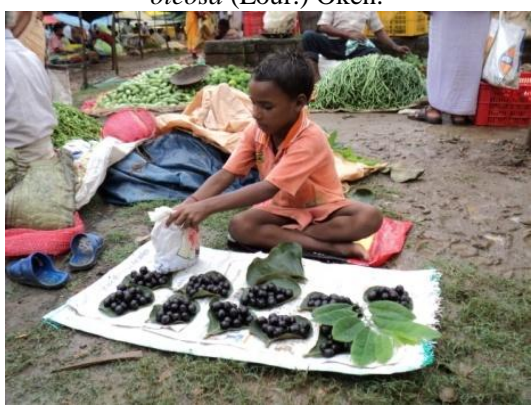

Syzigium cumini (Linn.) Skeels

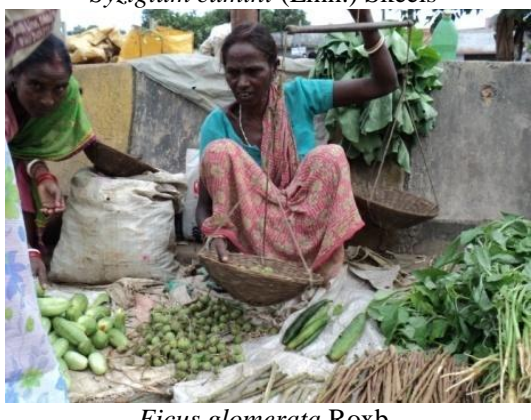

Ficus glomerata Roxb.

Figure 5 Forest fruits sustaining livelihood security of tribes

\section{Conclusion}

Collection of forest fruits is an important source of food, subsistence, cash income and a safety net for tribal people in Jharkhand. Poverty among the tribes is so overwhelming that huge bulk of the forest fruits is sold for cash income while a little fraction is retained for subsistence consumption. Although, the economic value of forest fruits is not analogous to the labours spent in the endeavor but the cash income accrued is significant to sustain the household livelihoods. Current unsustainable extraction, increased market pressures on fruit resources, loss of forests due to conversion to agriculture and rapid population growth are likely to decline the availability of forest fruits in near future. Further, the unbalanced interaction between the people and

Journal of Experimental Biology and Agricultural Sciences http://www.jebas.org 
the forest ecosystem is liable to worsen the success of conservation and sustainable management of edible fruits. Hence, sustainable forest management and conservation through forest access regulation is crucial to keep pace with the current development and future challenges. Awareness creation and capacity building of tribes in sustainable forest resources management, domestication, production, harvesting, handling, and value-addition of economically and culturally important fruits and entrepreneurship in micro-enterprises of forest fruit products are the future interventions which can compensate the conservations efforts and promote livelihood diversification for the poorest groups. The present findings on forest fruits-household income link suggest that the forest edible fruits should be given a due focus in development and policy implications to harmonize the livelihood improvement and poverty alleviation besides forest conservation in the tribal Jharkhand.

\section{Acknowledgment}

The authors are grateful to local tribal people, Gram Pradhans, clan heads, local leaders, Government officials and NGO workers of Bundu block for their participation, assistance and hospitality during the field works.

\section{Conflict of interest}

No conflict of interests among the authors.

\section{References}

Abdullah MR, Rahman MM, Hossain HA, Jalil MA (2020) Diversity of minor fruit species in two tribal communities of Sadar upazila, Khagrachari. Bangladesh. International Journal of Forestry, Ecology and Environment 1(2): 28-34. DOI: https://doi.org/10.18801/ijfee.010220.04.

Anonymous (2009) State of Jharkhand - Overview cited at http://jharenvis.nic.in, 2009 access on 29 April 1979.

Biswas SC, Majumdar M, Das S, Misra TK (2018) Diversity of wild edible minor fruits used by the ethnic communities of Tripura, India. Indian Journal of Traditional Knowledge 17(2): 282-289.

Brahma S, Narzary H, Basumatary S (2013) Wild edible fruits of Kokrajhar district of Assam, North-East India. Asian Journal of Plant Science and Research 3(6): 95-100. DOI: https://doi.org/10.21746/aps.2017.6.11.3

Chakraborty S, Chaturvedi HP (2014) Some wild edible fruits of Tripura-A survey. Indian Journal of Applied Research 4(9): 566-569.

Champion HG, Seth SK (1968) Revised survey of forest types in India. Manager of Publication, FRI Press, Dehra Dun, India.
Dangwal LR, Singh T, Singh A (2014) Exploration of wild edible plants used by Gujjar and Bakerwal tribes of District Rajouri (J\&K), India. Journal of Applied and Natural Science 6(1): 164169. DOI: 10.31018/jans.v6i1.394.

Deb D, Sarkar A, Deb Barma B, Datta BK, Majumdar K (2013) Wild edible plants and their utilization in traditional recipes of Tripura, Northeast India. Advances in Biological Research 7(5): 203-211.

Gangte HE, Thoudam NS, Ginzamang TZ (2013) Wild edible plants used by the Zou tribe in Manipur, India. International Journal of Scientific and Research Publications 3(5): 1-8.

Gireesha J, Raju NS (2013) Ethno-botanical study of medicinal plants in BR Hills region of Western Ghats, Karnataka. Asian Journal of Plant Science Research 3(5): 36-40.

Hazarika TK, Marak S (2019) Wild edible fruits of Meghalaya, North-East India: an unexplored potential for nutritional security and economic prosperity. Acta Horticulture 1241(104): 717-727. DOI: https://doi.org/10.17660/ActaHortic.2019.1241.104.

Hegazy AK, Mohamed AA, Ali SI, Alghamdi NM, Abdel-Rahman AM, Al-Sobeai S (2019) Chemical ingredients and antioxidant activities of underutilized wild fruits. Heliyon 5(6): 1-8.

Islam MA, Quli SMS (2016) Non-timber forest products (NTFPs) supporting food security in tribal Jharkhand. Jharkhand Journal of Development and Management Studies 14(1): 6855-6864. DOI: https://doi.org/10.20546/ijcmas.2017.610.259.

Islam MA, Rai R, Quli SMS, Tramboo MS (2015) Socio-economic and demographic descriptions of ethnic people subsisting in forest resources of Jharkhand, India. Asian Journal of Bio Science 10(1): 75-82. DOI: 10.15740/HAS/AJBS/10.1/75-82

Khatoon R, Singh PK, Das AK, Dutta BK (2012) Indigenous wild edible fruits for Kom tribe in Manipur, India. Pleione 6(2): $268-272$.

Lyngdoh N, Piloo N, Gab T, Kumar M, Pandey AK (2016) Wild edible fruit tree resources of Arunachal Pradesh, North East India. Journal of Applied and Natural Science 8(2): 883-889. DOI:10.31018/jans.v8i2.891.

Mahapatra AK, Panda PC (2012) Wild edible fruit diversity and its significance in the livelihood of indigenous tribals: Evidence from eastern India. Food Security 4(2): 219-234. DOI: 10.1007/s12571012-0186-z.

Mairh AK, Mishra PK, Kumar J, Mairh A (2010) Traditional botanical wisdom of Birhore tribes of Jharkhand. Indian Journal of Traditional Knowledge 9(3): 467-470. 
Majumdar K, Datta BK (2009) Traditional wild edible fruits for the forest dwellers of Tripura, India. Pleione 3(2): 167-178.

Mukherjee N (1993) Participatory Rural Appraisal: Methodology and Applications, Concept Publishing Company, Delhi, pp. 46-62.

Muzaffer M, Lutfi B, Ugur C (2016) Survey of wild food plants for human consumption in villages of Catak (Van-Turkey). Indian Journal of Traditional Knowledge 15(2): 183-191.

Neudeck L, Avelino L, Bareetseng P, Ngwenya BN, Teketay D, Motsholapheko MR (2012) The contribution of edible wild plants to food security, dietary diversity and income of households in Shorobe Village, northern Botswana. Ethnobotanical Research and Applications 10(1): 449-462.

Ray GL, Mondol S (2004) Research Methods in Social Sciences and Extension Education, Kalyani Publishers, New Delhi, Pp. 66-76.

Sahu C (2008) Cultural identity of tribes of Jharkhand. Jharkhand Journal of Development and Management Studies 1(1): 139-145.

Sarmah BP, Baruah D, Bakalial B (2013) Wetland medicinal plants in flood plains of Subansiri Ranga river of Lakhimpur district, Assam, India. Asian Journal of Plant Science Research 3(3): 54-60.

Seal T, Pillai B, Chaudhary K (2014) Nutritional potential of wild edible fruits traditionally used by the local people of Meghalaya state in India. Indian Journal of Natural Products and Resources 5(4): 359-364.

Seyoum Y, Teketay D, Shumi G, Wodafirash M (2015) Edible Wild Fruit Trees and Shrubs and Their Socioeconomic Significance in Central Ethiopia. Ethnobotany Research an Applications 14(2): 183-197.

Shah AH, Shah AH, Mehmood A, Khan KR, Farooq M, Zohra L
(2019) Nutraceutical Exploration of Wild Edible Fruits of District Tor Ghar, Northern Pakistan. European Online Journal of Natural and Social Sciences 8(3): 459-468.

Shan S, Huang X, Shah MH, Abbasi AM (2019) Evaluation of polyphenolics content and antioxidant activity in edible wild fruits. Hindawi BioMed Research International 1(2): 1-11. doi: $10.1155 / 2019 / 1381989$.

Shivprasad M, Rane M, Manik P (2016) Traditional uses of some wild edible fruits from Palghar district. Journal of Natural Products and Plant Resources 6(6): 8-11.

Singh B, Sinha BK, Phukan SJ, Borthakur SK, Singh VN (2012) Wild edible plants used by Garo tribes of Nokrek Biosphere Reserve in Meghalaya, India. Indian Journal of Traditional Knowledge 11(1): 166-171.

Sinha R, Lakra V (2005) Wild tribal food plants of Orissa. Indian Journal of Traditional Knowledge 4(3): 246-256.

Slathia PS, Paul N, Gupta SK, Sharma BC, Kumar R, Kher SK (2017) Traditional uses of under-utilized tree species in sub tropical rainfed areas of Kathua, Jammu \& Kashmir. Indian Journal of Traditional Knowledge 16(1): 164-169.

Snedecor G, Cochran WG (1967) Statistical Methods. Iowa State Univ. Press, Ames, Iowa, USA, pp 17-36.

Srivastava R (2013) Underutilised fruits: a potential of local food resource. International Journal of Pharma and Bio Sciences 4(3): 1301-1305.

Zhai H, Wang, Y, Jiang W (2020) Fruit and Vegetable Intake and the Risk of Chronic Obstructive Pulmonary Disease: A DoseResponse Meta-Analysis of Observational Studies. BioMed Research International 2020: 1-12. DOI: https://doi.org/10.1155/2020/3783481. 